\title{
Diversity and distribution of introduced and potentially invasive ant species from the three main ecoregions of Côte d'Ivoire (West Africa)
}

\author{
Lombart M. Maurice Kouakou ${ }^{1, *}$, Wouter Dekoninck ${ }^{2}$, \\ Mouhamadou Kone ${ }^{3}$, Thibaut Delsinne ${ }^{4}$, Kolo Yeo ${ }^{1}$, \\ Kaly Ouattara $^{1} \&$ Souleymane Konate ${ }^{1}$
}

\footnotetext{
${ }^{1}$ Station d'écologie de Lamto, Université Nangui Abrogoua, BP 28 N'Douci, Côte d'Ivoire.

${ }^{2}$ Royal Belgian Institute of Natural Sciences, Rue Vautier 29, B-1000 Brussels, Belgium.

${ }^{3}$ Université Pelifero Gon Coulibaly de Korhogo, Côte d'Ivoire.

${ }^{4}$ Société d'Histoire Naturelle Alcide-d'Orbigny 57 rue de Gergovie, 63170 Aubière, France

*Corresponding author: lom-bart@hotmail.fr
}

\begin{abstract}
An important issue in biodiversity conservation is the early detection of introduced and invasive organisms and identification of regions that may either be points of introduction or be particularly prone to invasion. Among insects, ants are easily transported worldwide by humans, and several species, such as Solenopsis geminata or Pheidole megacephala, can be highly invasive. To establish an initial baseline for urban ant monitoring in Côte d'Ivoire (Western Africa), fifteen cities - equally distributed over the three main ecoregions of the country - were surveyed using tuna baits as sampling method. A total of 103 ant species from 22 genera and 5 subfamilies were collected. We identified 10 potentially invasive species, amongst them two new species for the country: Solenopsis geminata and Solenopsis globularia. Another highly invasive species, Paratrechina longicornis, was the most abundant species collected throughout the country. Potentially invasive ant species co-occurred with non-invasive species, and contributed importantly to the structure of ant assemblages of all sampled urban habitats. The present study provides evidence that introduced and invasive ant species are established in cities of Côte d'Ivoire, often in high numbers and are occurring over large areas of invasion.
\end{abstract}

KEYWORDS. Biodiversity, invasive ants, ecoregions, urban habitats, Côte d'Ivoire.

Kouakou L.M.M., Dekoninck W., Kone M., Delsinne T., Yeo K., Ouattara K. \& Konate S. (2018). Diversity and distribution of introduced and potentially invasive ant species from the three main ecoregions of Côte d'Ivoire (West Africa). Belgian Journal of Zoology 148 (1): 83-103. https://doi.org/10.26496/bjz.2018.19

\section{Introduction}

The accelerated growth in the numbers of people living in cities leads to the rapid expansion of urban areas (UN 2010; SETO et al. 2011). Cities inside or near biodiversity hotspots may cause the local extinction of native and endemic species and the homogenization of the world's biota (MCKINNEY 2006; MCDONALD et al. 2013; FERLAND 2015). A major concern is the increase in introductions of exotic and invasive species, associated with increasing transport of people and goods across the globe 
and the consequent disturbance of urban areas, which sharply increases the opportunities of non-native species to be introduced and become invasive outside their geographical range (MCKINNEY 2006; KOWARIK \& VON DER LiPPE 2007; Hulme 2009; SCDB 2014; MOlinA-MONTENEGRO et al. 2014). For example, human settlements import exotic species through commercial exchange and tourism. Due to the increased disturbance of urban areas these species spread into adjacent landscapes along transport corridors (airports, ports, railways, waterways, industrial zones, roads) and in many cases invade natural areas where they cause deleterious effects on biodiversity and enormous resultant economic costs once they are established (EHRENFELD 2010; Pimentel 2011; SimBERLOFF \& REJMÁNEK 2011).

Given the strong implication of humans in the introduction of exotic and invasive species, many authors reported cities as hotspots of invasion and consider urban ecosystems as important pathways and vectors for propagule dispersal (MCKINNEY 2006; VON DER LIPPE \& KOWARICK 2008; VAN HAM et al. 2013). Moreover, despite the recommendation of Aichi target 9 throughout the strategy Plan of Biodiversity (2011-2020) to identify invasive species and pathways, basic studies on native and introduced biota in urban landscapes remain rare or missing for many developing countries. This is especially the case in the West African urban landscapes where the biodiversity of the Guinean Forest (West African major biodiversity hotspot) will undergo direct impact of urbanization by 2030 (SETO et al. 2013).

In this study we examine urban ant communities from the three ecoregions of Côte d'Ivoire with the aim of identifying introduced and potentially invasive ants. We focused on these insects because they are one of the most important arthropod groups in tropical ecosystems (HÖLLDOBLER \& WILSON 1990) and are easy to collect (AGOSTI \& ALONSO 2000). Many of them have a generalized diet and are able to adapt to urban habitats (ANGILLETTA et al. 2007; GUENARD et al. 2014). These ant species, called "tramp species" are abundant in human settlements and could occur outside their original distributional range (MCGLYNN 1999). The small size of these ant species makes them easily transported unintentionally by humans via tourism and commercial exchange (HolwAY et al. 2002). Consequently, for over 200 ant species that have been reported as introduced in exotic ranges, many of them are among the world's notorious invaders (MCGLYNN 1999; SUAREZ et al. 2010). Invasive ants cause ecological and economic damage. They are responsible for the loss of diversity of ants, other arthropods and even vertebrates in many invaded regions (HOLWAY et al. 2002; SIMBERLOFF et al. 2013; WAUTERS et al. 2014). Yet, studies on the status of ant invasion in Africa are lacking (SUAREZ et al. 2010), particularly in West Africa, Côte d'Ivoire, where all existing studies on ants to date have been conducted in natural habitats and agricultural ecosystems (LEVIEUX 1971; DiOMANDÉ 1981; YeO 2006; YeO et al. 2011; KonÉ 2013). The urban habitat has not been screened sufficiently for its ant fauna.

Here, we study ant diversity and composition in urban landscapes of Côte d'Ivoire with a particular focus on the identification of invasive ant species. The specific objectives were: (1) to compare the distribution and diversity of urban ant communities within three ecoregions of the country (2) to identify and estimate the importance of introduced and potentially invasive ant species in different ecoregions, and (3) to assess the contribution of potentially invasive and dominant ant species to the ant assemblage in the three ecoregions.

\section{Material and methods}

\section{Study sites}

The study was conducted in fifteen cities of Côte d'Ivoire (Table S1). Côte d'Ivoire is located in West Africa ( $4^{\circ} 30^{\prime}$ to $10^{\circ} 30^{\prime} \mathrm{N}$ and $2^{\circ} 30^{\prime}$ to $8^{\circ} 30^{\prime} \mathrm{W}$ ) and covers an area of $332,462 \mathrm{~km}^{2}$. It is bordered to the west by Liberia and Guinea, to the east by Ghana, to the north by Mali and Burkina Faso and to the south by the Atlantic Ocean. The current population is 22,671,300 inhabitants, half of them living in cities (RGPH 2014). The hot and humid climate ranges between equatorial and tropical with $28^{\circ} \mathrm{C}$ annual mean temperature and annual precipitation varying between $1000 \mathrm{~mm}$ in the North to $2400 \mathrm{~mm}$ 
in the South (SAVANE \& KonARE 2010). Côte d'Ivoire is divided in three ecoregions: Sudanian, GuineoCongolian (White 1983; GAUTIER \& SPICHIGER 2003) and Transition (Fig. 1).

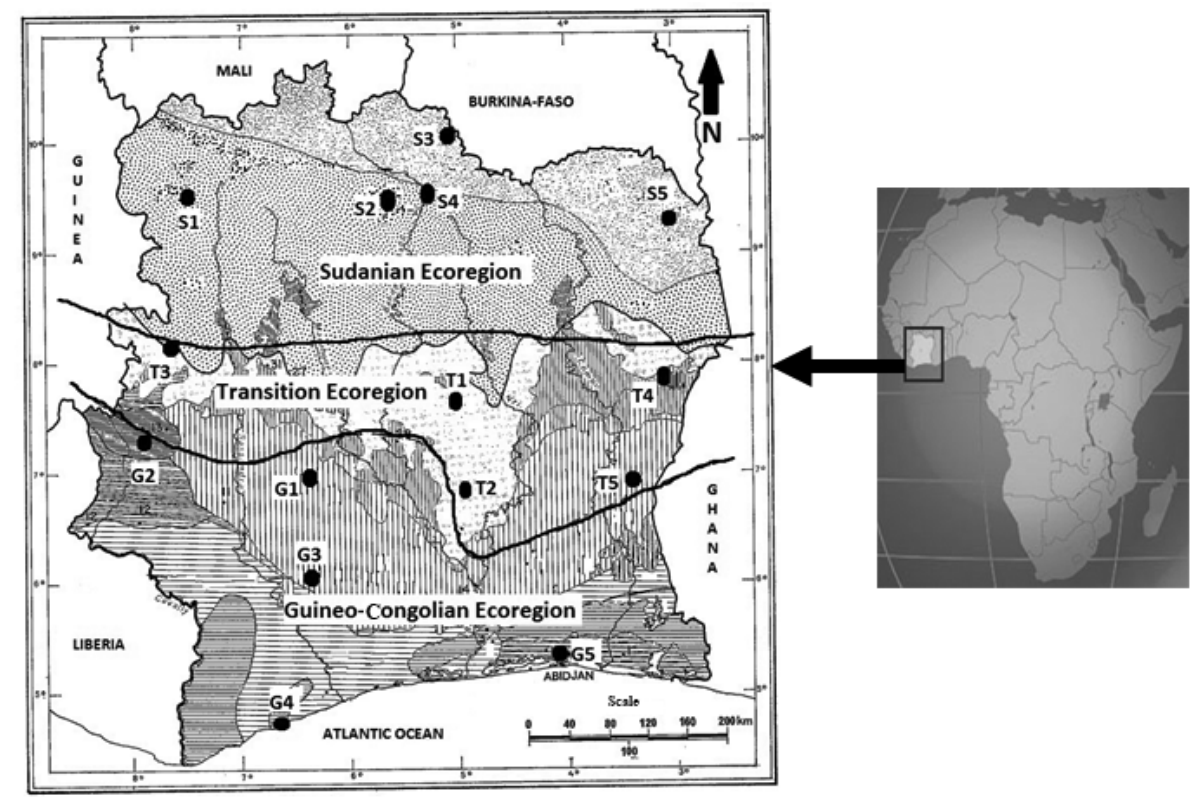

Fig. 1 - Map of location of the 15 cities monitored and type of vegetation of Côte d'Ivoire (modified after AVENARD et al. 1971). S1-S5: cities of Sudanian ecoregion; T1-T5: cities of Transition ecoregion and G1-G5: cities of Guineo-Congolian ecoregion.

The Sudanian ecoregion is located in the North and consists of sparsely wooded forests, wooded and grassy savannahs set on lateritic soil. The cities of this ecoregion are poorly urbanized because a large part of the population is living in rural areas (COTTEN 1974; RGPH 2014). The cities of Odienné (S1), Korhogo (S2), Ouangolodougou (S3), Ferkessedougou (S4), and Bouna (S5) are located in this ecoregion. The urban land development is low in the cities of this ecoregion. The restricted asphalted road and reduced pavement also favour the presence of bushy vacant lots, permanently restricted lots covered by native vegetation (Table S1).

The Guineo-Congolian ecoregion covers the southern half of the country and comprises the majority of biodiversity hotspots because of the presence of dense humid forests. The cities of this ecoregion are the most densely populated and urbanized. The migration of people from the other ecoregions towards the Guineo-Congolian ecoregion due to the presence of many cocoa plantations, cash crops economy and its proximity to the coast has contributed to a sprawl and industrialization of cities in this ecoregion (BeAuChemin 2002; Chatelain et al. 2003; HALle \& BRUZON 2006). The surveyed cities in this ecoregion were Daloa (G1), Man (G2), Soubre (G3), San-Pedro (G4) and Abidjan (G5) characterized by a high occupation of urban land by settlements and urban infrastructure. In the cities of this ecoregion, urban land is densely paved and open areas are rarely covered by ruderal vegetation and grasses, apart from the managed green spaces (Table S1).

The Transition ecoregion consists of savannah/forest mosaics (KEAY 1959). It consists of semideciduous forest embedded within the Guinean savannah. Here we surveyed the cities of Bouake (T1), Yamoussoukro (T2), Touba (T3), Bondoukou (T4) and Abengourou (T5). Cities of this ecoregion are the most populated after the Guineo-Congolian cities, with expansive industrial zones in the cities of 


\section{TABLE 1}

Number of species occurrences, species richness, estimated species number (Chao 2), sampling coverage $(=[$ observed species number / estimated species number $] * 100)$ and number of unique species for each ecoregion.

\begin{tabular}{lcccccc}
\hline Ecoregions & $\begin{array}{c}\text { N bait } \\
\text { samples }\end{array}$ & $\begin{array}{c}\text { N occur- } \\
\text { rences }\end{array}$ & $\begin{array}{c}\text { N species } \\
\text { observed }\end{array}$ & $\begin{array}{c}\text { N estima- } \\
\text { ted species }\end{array}$ & $\begin{array}{c}\text { Sampling } \\
\text { coverage } \\
(\%)\end{array}$ & $\begin{array}{c}\text { N unique } \\
\text { species }\end{array}$ \\
\hline Sudanian ecoregion & 300 & 1708 & 63 & 82 & 77 & 19 \\
Transition ecoregion & 300 & 1675 & 54 & 67 & 81 & 14 \\
Guinean-Congolian ecoregion & 300 & 2060 & 56 & 74 & 76 & 7 \\
Ecoregions combined & 900 & 5443 & 103 & 146 & 71 & 31 \\
\hline
\end{tabular}

Bouaké and Yamoussoukro. Urban land development is moderate with open areas covered by patches of verdure alternating between lawns, grass and isolated trees (Table S1).

\section{Sampling and identification}

We collected samples between 8:00 am and 12:00 am from September 2014 to December 2015 in seven specific habitats described as follows: Domestic street: roads and streets without asphalt located between houses; Market: sites near traditional daily markets; Residential: houses where people of middle-class live; Asphalted street: road dominated by asphalt; Transport station: sites of transport of people and goods; Industrial zone: areas dominated by industrial activities such as production, transformation, exportation and importation of goods; Harbour zone: Port area of Abidjan and San-Pedro. The latter two types of habitat are linked to ports. We considered all these habitats as being different in environmental disturbance and their ability to house introduced and potentially invasive ant species.

Our sampling sites were cities (five cities per ecoregion). In each city, sampling was conducted on three distinct transects. Transects were linear lines of 200 metres with 20 sampling points separated by 10 metres from each other. A brief description of each transect was done and the transects were georeferenced with a Garmin GPSMAP 64s in order to characterize the physical environment of sampling area (Table S1). Ants were collected using tuna baits at each sampling point at 15, 30, 45 and 60 minutes (YEO et al. 2016). Each sample was stored in an individual Eppendorf minitube of $2 \mathrm{ml}$ filled with Ethanol $(96 \%)$ and labelled. The fifteen sampled cities were distributed equally among the three ecoregions with a total number of 45 transects, yielding a total of 900 bait samples (Table 1).

Ant workers were identified at genus level using BOLTON's (1994) identification guide. We then used identification keys of BolTon $(1976,1980,1982,1987)$ and Dr Yeo Kolo's personal ant reference collection in Lamto Ecological Station for identification at species level. Ants of the latter collection are used as reference for Côte d'Ivoire because they were identified based on ant specimens deposited at Natural History Museum of London, Musée d'Histoire Naturelle de Paris and the Museum of Comparative Zoology, Cambridge, USA, or checked by ant taxonomists during Yeo's PhD thesis (YEO 2006). When possible ant specimens were digitized using the digitization equipment at Royal Belgian Institute of Natural Sciences (RBINS) (BRECKO et al. 2014) and compared with the image bank on AntWeb (www.antweb.org). All identified ant specimens were deposited at RBINS and in Lamto Ecological Research Station, Côte d'Ivoire. Because of the absence of historical data on introduced, invasive, and most native ants in Côte d'Ivoire, we screened the literature to determine the introduced and potentially invasive status of the ants we identified. Consequently, we assessed the introduced and/or potentially invasive status when they were reported as non-native from Africa and/or invasive elsewhere in the world (MCGlynN 1999; Holway et al. 2002; BERMAn et al. 2013; WeTtERER 2010a, 2010b, 2011, 2012, 2015; WETTERER \& GARCIA 2015). We also used the websites of the Global Biodiversity Information 
KOUAKOU L.M.M. et al., Introduced and invasive ant communities in Côte d'Ivoire

Facilities (GBIF; www.gbif.org), Encyclopedia of Life (EOL; www.eol.org) and PIAkey (SARNAT 2008) to find out what the current status of several ant species in Western Africa might be.

\section{Data analysis}

The transect was considered as sampling unit for the analysis of data. Thus, the occurrences of species (presence or absence data) were considered rather than the absolute number of individuals (ant workers). This measure was preferred because of the patchy distribution of ants due to their social organization (LONGINO 2000) and due to great differences in colony sizes (ANDERSEN 1991). At transect level, we pooled samples of 15, 30, 45 and 60 minutes from the same bait to get a total of 20 samples per transect. At the city level we combined the three corresponding transects (60 samples) and at the ecoregion level we grouped all transects (300 samples) from the corresponding cities. We measured our sampling success by estimating the expected species richness with a nonparametric estimator (Chao 2) included in EstimateS v. 9.1.0 (COLWELL 2005).

For each transect and city we calculated the average number of ant species $(\mathrm{S})$, the total number of worker occurrences $(\mathrm{N})$ and Margalef diversity index. Using these indices, we conducted a diversity partitioning according to WAGNER et al. (2000). We deconstructed the entire community diversity into its alpha component at three levels: diversity among transects within cities, diversity among cities within ecoregion and diversity among ecoregions. In addition, we examined how spatial scale affects introduced and potentially invasive ant species. For that, only introduced and potentially invasive species were included in the species diversity partitioning. Differences in the absolute number of introduced and potentially invasive species between transects of the three ecoregions were compared using nonparametric Friedman test on repeated measures. The complementarity between the three ecoregions was measured using Bray-Curtis similarity index. Further, transects were ordinated by means of a non-metric multidimensional scaling (NMDS) based on the Bray-Curtis similarity index. We further used values of Bray-Curtis index to perform an analysis of similarities (ANOSIM), using 10000 permutations to test for significant differences in species composition between transects and ecoregions. This analysis compares the differences amongst average rank similarities between samples of transects and cities within ecoregions and between samples in distinct ecoregions. It provides an $R$ statistic which is a measure of the dissimilarity between sites. Values of $R$ close to zero indicate low dissimilarities while values of $R$ closer to 1 indicate high dissimilarities (CLARKE \& GREEN 1988). Finally, we carried out a similarity percentage analysis (SIMPER) to determine which species contribute the most to the similarity in species composition among sites (Clarke 1993). The calculation of indexes of $\alpha$-diversity, complementarity, ANOSIM and SIMPER analyses were performed, using Past Software 3.09 (HAMMER et al. 2001).

\section{Results}

In total we collected 60437 ant workers (5443 occurrences) representing 103 species from 22 genera and 5 subfamilies (Table 1; Table S2). Myrmicinae (77 species) was the most speciose subfamily, followed by Formicinae (15 species) Dolichoderinae and Ponerinae, with 4 species each. The subfamily Dorylinae (3 species) was the least speciose. However we noticed that the Dolichoderinae were more abundant in the Guineo-Congolian ecoregion while a different pattern was observed for Ponerinae (Table S2). Dorylinae were rare in urban areas.

Out of 103 species, we identified 10 introduced and potentially invasive ant species, which constitute an important part (21.80\%) of the total occurrences (Table S2). The following species were considered as being introduced and potentially invasive: Paratrechina longicornis (8.7\%), Tetramorium simillimum (3.5\%), Trichomyrmex destructor (3\%), Pheidole megacephala (3\%), Monomorium pharaonis $(1.2 \%)$, Cardiocondyla emeryi (1\%), Tapinoma melanocephalum (0.5\%), Solenopsis geminata $(0.4 \%)$, Tetramorium caldarium $(0.42 \%)$ and Monomorium floricola $(0.07 \%)$. The proportion of transects on 


\section{TABLE 2}

Number of potentially invasive ant species, percentage of transects with potentially invasive species and mean number $( \pm \mathrm{SD})$ of introduced and potentially invasive ant (tramp) species per transect in the three ecoregions. ( $\mathrm{n}=15$ transects per ecoregion).

\begin{tabular}{lccc}
\hline Regions & $\begin{array}{c}\text { N potentially } \\
\text { invasive ant } \\
\text { species }\end{array}$ & $\begin{array}{c}\text { \% transects with } \\
\text { potentially invasive } \\
\text { ants }\end{array}$ & $\begin{array}{c}\text { Mean number of introduced } \\
\text { and potentially invasive } \\
\text { ants per transect }\end{array}$ \\
\hline Sudanian ecoregion & 7 & 93 & $2.8 \pm 1.3$ \\
Transition ecoregion & 8 & 100 & $3.2 \pm 0.8$ \\
Guineo-Congolian ecoregion & 10 & 100 & $3.5 \pm 1.6$ \\
\hline
\end{tabular}

which these species co-occur with native species is indicated in Table 2. Introduced and potentially invasive ants species were detected on all transects in the Guineo-Congolian and the Transition ecoregions, while in the Sudanian ecoregion only one transect was exempt from these ant species. Comparison of the average number of introduced and potentially invasive ant species did not show significant differences between transects of the three ecoregions (Friedman test: $\chi 2=1.6, d f=2, P=$ $0.37)$. However, abundance of introduced and potentially invasive ant species varied significantly between ecoregions (Friedman test: $\chi^{2}=3.6, d f=2, P=0.014$ ) (Fig. 2). Paratrechina longicornis, Trichomyrmex destructor, Tetramorium simillimum and Pheidole megacephala were the most abundant potentially invasive ant species.

Considering the whole ant community together, ant species composition differed among ecoregions (general ANOSIM: $R=0.38, P<0.005$, Table 3; Fig. 5). We also noticed that species composition in some cities of the Transition ecoregion was more similar to cities of the Sudanian and Guineo-congolian ecoregions. Comparison of ant species composition separately indicated that composition of native ant species differed between ecoregions (ANOSIM: $R=0.31, P<0.001$ ) while a low difference was observed in composition of introduced and potentially invasive ant species (ANOSIM: $R=0.05, P<0$. 04). Furthermore, similarity percentage analysis (SIMPER) showed that 20 ant species contributed

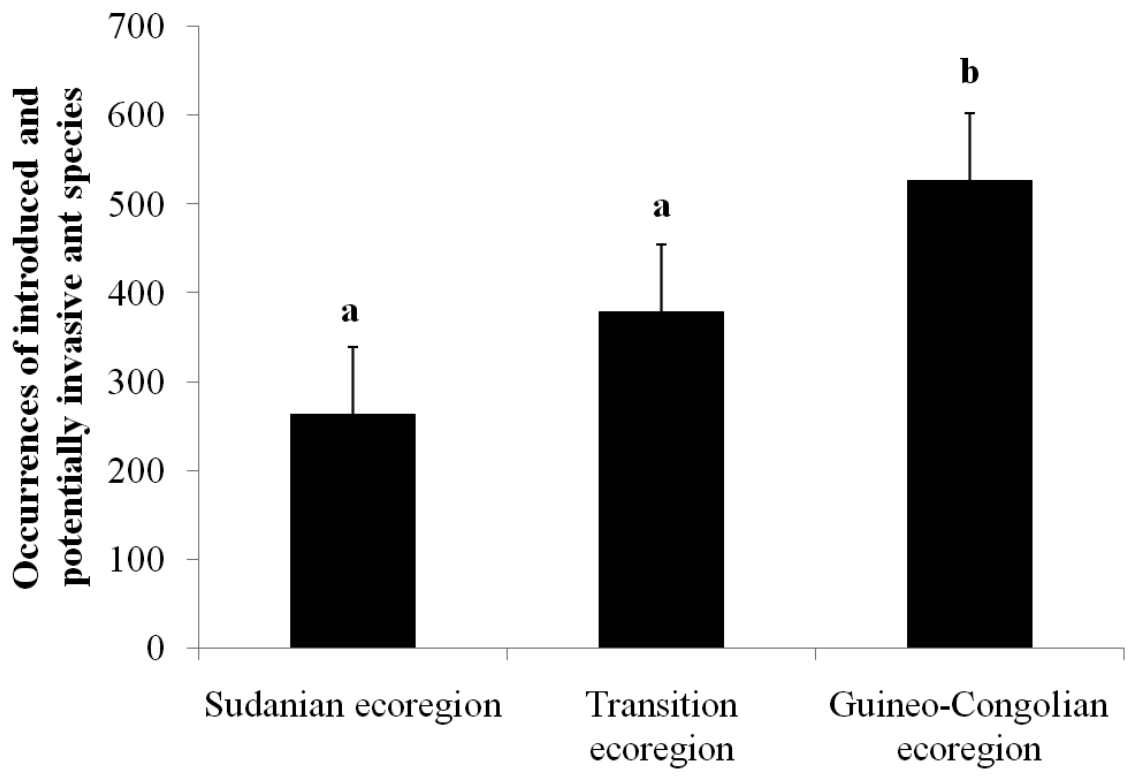

Ecoregions

Fig. 2 - Occurrences of introduced and potentially invasive ant species recorded in Sudanian, Transition and Guineo-Congolian ecoregions. 
TABLE 3

Differences in species composition of ant assemblages from the three ecoregions of Côte d'Ivoire tested by means of pairwise ANOSIM comparisons.

\begin{tabular}{lcc}
\hline Pairwise test & R & $\boldsymbol{p}$ \\
\hline Sudanian vs Transition & 0.28 & 0.038 \\
Sudanian vs Guineo-Congolian & 0.70 & 0.008 \\
Transition vs Guineo-Congolian & 0.16 & 0.165 \\
\hline
\end{tabular}

the most to the average dissimilarity among species assemblages from different ecoregions (Table 4). These ant species contributed up to $70 \%$ of the global ant similarity. Among them, four introduced and potentially invasive ant species occurred: Paratrechina longicornis, Trichomyrmex destructor, Pheidole megacephala and Tetramorium simillimum.

Examination of sampling effectiveness indicated that sample coverage was more than $70 \%$ of all ecoregions, although species accumulation curves did not reach a plateau (Fig. 3). The total number of 103 species was divided into 63, 56 and 54 ant species in the Sudanian, Guineo-Congolian and Transition ecoregions, respectively. Figure 4 shows the partitioning of observed species richness (S) and diversity in additive component. For observed species number (S), the total of 103 species can be divided into a mean (S) within-city richness of 25 species and a between-city richness of 78 species. When split among ecoregions, observed species numbers can be divided into a mean (S) within-city richness of 27, 25 and 23 species, and a between-city richness of 36, 29 and 33 species for Sudanian, Transition and Guineo-Congolian ecoregions, respectively. In addition, the comparison of observed species number at the lowest level (between transects) of ecoregions did not show significant difference (Friedman test: $\chi 2=4.13, d f=2, P=0.11$ ). Within and between- transects and cities Margalef diversity index (d), shows that ant diversity decreased significantly from the Sudanian ecoregion $(2.9 \pm 0.91)$ towards the Transition ecoregion (2.8 \pm 0.57$)$ and the Guineo-Congolian ecoregion $(2.5 \pm 0.63)(\chi 2=6.53$, $d f=2, P=0.04$ ) (Fig. 4; Table 5). For the observed number of introduced and potentially invasive ant species, a total of 10 species can be divided into a means within-city richness of 5 species and a between-city richness of 5 species. In the ecoregions, observed numbers of species of introduced and potentially invasive ant species can be divided into a mean (S) within-city richness of 3, 3 and 4 species,

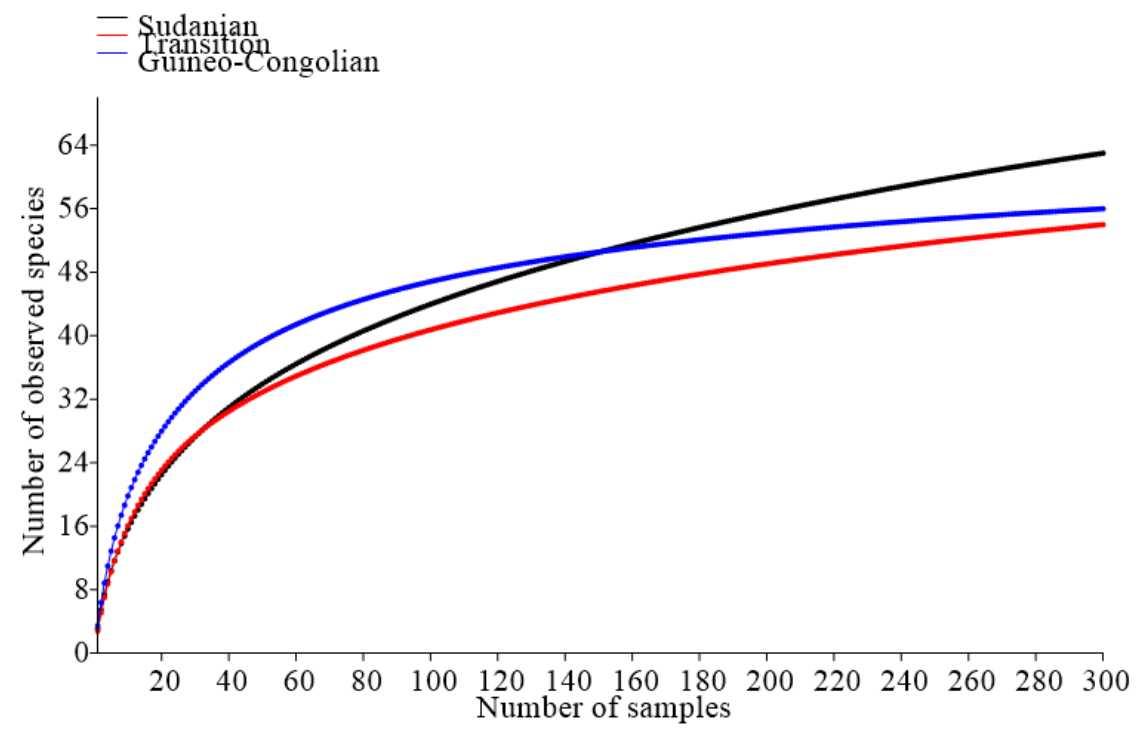

Fig. 3 - Observed number of ant species accumulation curve for the Sudanian, Transition and GuineoCongolian ecoregions. 
and a between-city richness of 4, 5 and 6 species for the Sudanian, Transition and Guineo-Congolian ecoregions, respectively.

\section{Discussion}

Out of 103 ant species collected in this study, ten might be considered as introduced and potentially invasive (MCGLYNN 1999; DEYRUP et al. 2000; HOLWAY et al. 2002; BERMAN et al. 2013; WeTtERER 2010a, 2010b, 2011, 2012, 2015; WETTERER \& GARCIA 2015; MAJID et al. 2016). These species are Paratrechina longicornis, Trichomyrmex destructor, Tetramorium simillimum, Pheidole megacephala,

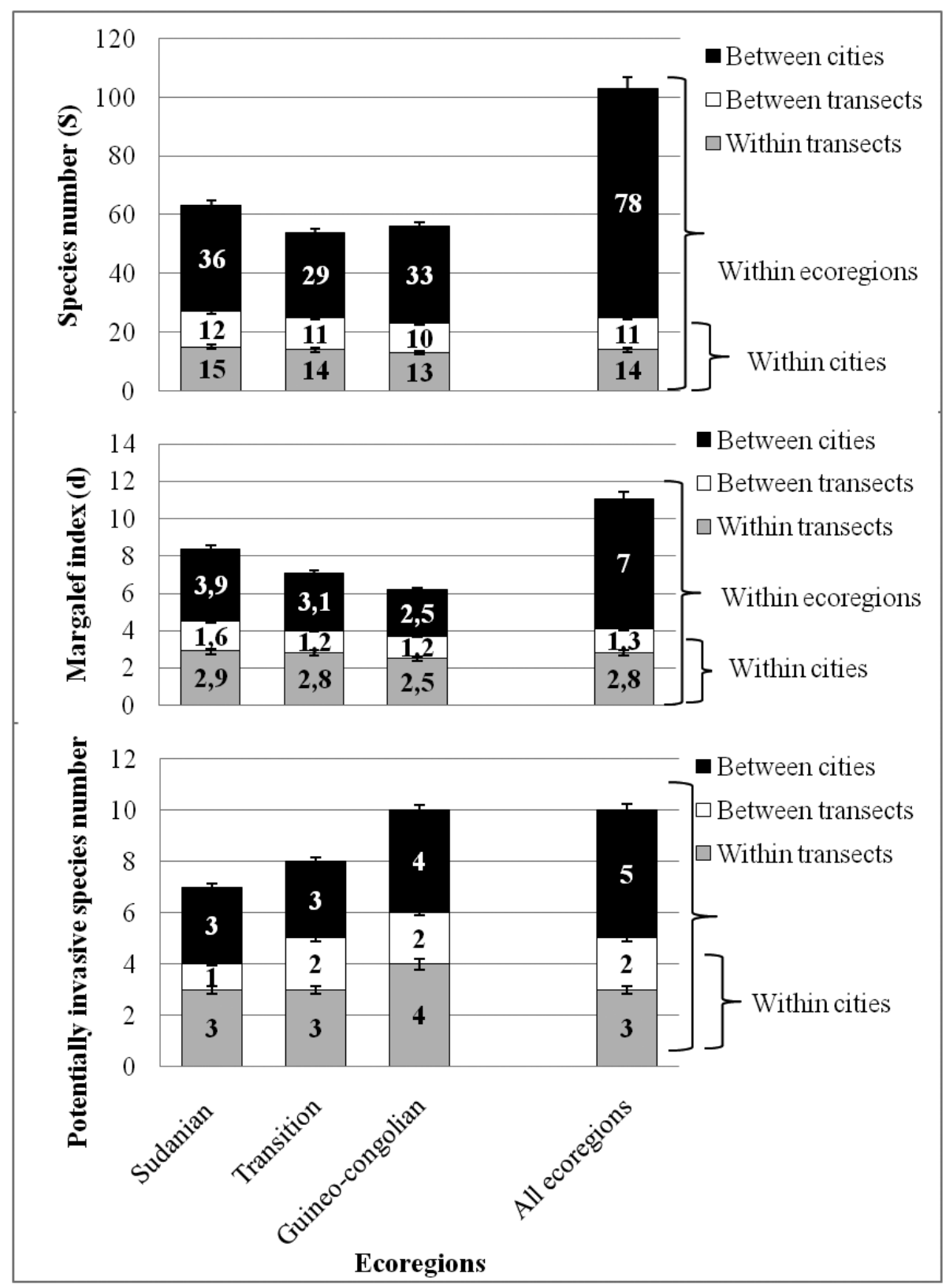

Fig. 4 - Additive diversity partitioning of the species number (top), Margalef index (middle) and introduced and potentially invasive species numbers (bottom) for the three ecoregions and the study area as a whole. The diversity was partitioned at three levels (transects, cities and ecoregions) into the mean species number (S), the mean Margalef index (d) and the mean number of introduced and potentially invasive ant species. 
TABLE 4

Non-invasive (NI) and introduced and potentially invasive (PI) ant species contribution (\%) to the average dissimilarities between ecoregions determined by SIMPER analysis. Abbreviations: NI = noninvasive species; PI = introduced or potentially invasive species. Status based on WETTERER 2010, 2011, 2012, 2014, 2015, 2016; BERMAN et al. 2013; MCGLYNN 1999 and HOLWAY et al. 2002).

\begin{tabular}{lcccc}
\hline & Status & $\begin{array}{c}\text { Sudanian/ } \\
\text { Transition }\end{array}$ & $\begin{array}{c}\text { Sudanian/ } \\
\text { Guineo-Congo- } \\
\text { lian }\end{array}$ & $\begin{array}{c}\text { Transition/ } \\
\text { Guineo- } \\
\text { Congolian }\end{array}$ \\
\hline Pheidole sp.1 & NI & 10.56 & 10.88 & 3.13 \\
Monomorium bicolor & NI & 7.50 & 5.29 & 8.52 \\
Pheidole termitophila & NI & 6.25 & 5.45 & 5.55 \\
Brachyponera sennaarensis & NI & 5.49 & 5.12 & 7.25 \\
Pheidole excellens & NI & 5.04 & $<1$ & 4.27 \\
Pheidole sp.2 (termitophila) & NI & 4.93 & 5.29 & 6.52 \\
Pheidole sp.20 & NI & 3.58 & 3.97 & 3.41 \\
Monomorium occidentale & NI & 3.55 & 5.28 & 5.42 \\
Pheidole sp.19 & NI & 1.74 & 3.99 & 4.49 \\
Tapinoma luteum & NI & $<1$ & 2.18 & 2.55 \\
Solenopsis globularia & NI & $<1$ & 2.96 & 3.31 \\
Paratrechina longicornis & PI & 5.48 & 5.72 & 6.108 \\
Trichomyrmex destructor & PI & 3.97 & 3.85 & 5.75 \\
Pheidole megacephala & PI & 3.78 & 2.08 & 2.94 \\
Tetramorium simillimum & PI & 2.36 & 3.75 & 2.82 \\
Monomorium pharaonis & PI & 1.24 & 1.33 & 1.23 \\
Monomorium floricola & PI & $<1$ & $<1$ & $<1$ \\
Tetramorium caldarium & PI & 1.05 & $<1$ & $<1$ \\
Tapinoma melanocephalum & PI & $<1$ & 3.33 & 3.76 \\
Cardiocondyla emeryi & PI & $<1$ & 1.08 & 1.09 \\
Solenopsis geminata & PI & 0 & $<1$ & 1.01 \\
\hline Contribution of potential invasive species & 16.83 & 21.14 & 24.7 \\
\hline Total contribution & & 67.52 & 73.55 & 79.12 \\
\hline
\end{tabular}

Monomorium pharaonis, Cardiocondyla emeryi, Tapinoma melanocephalum, Solenopsis geminata, Tetramorium caldarium and Monomorium floricola. Their detection demonstrates that introduced and potentially invasive ant species already occur in ant communities of urban areas in the Côte d'Ivoire and often at high occurrences. These findings are consistent with other studies (KARK et al. 2007; MACK \& LONSDALE 2001) demonstrating that species from urban ecosystems are derived from a pool of native and introduced species, including invasive species. In addition, potentially invasive ant species were frequently present in our study and they represent $21.79 \%$ of the total urban ant species occurrences. Their occurrence increases from the cities of Sudanian ecoregion towards the cities of Guineo-Congolian ecoregion. This pattern might be explained by the impact of humans throughout urban land development in these different ecoregions. As also reported in other studies on invasive ant species (NARENDRA et al. 2011; VONSHAK \& Gordon 2015), differences in occurrence of introduced and potentially invasive ant species could be due to the impact of human activities. Our comparison of species composition between 


\section{TABLE 5}

Alpha-diversity (mean $\pm \mathrm{SD}$ ) of ant communities based on transects in Sudanian, Transition and GuineoCongolian ecoregions of Côte d'Ivoire ( $\mathrm{n}=15$ transects/ecoregion).

\begin{tabular}{lccc}
\hline & $\begin{array}{c}\text { Observed species (S) at } \\
\text { transects level }\end{array}$ & $\begin{array}{c}\text { Margalef } \\
\text { index (d) }\end{array}$ & Equitability (j) \\
\hline Sudanian ecoregion & $15 \pm 1.14$ & $2.93 \pm 0.91$ & $0.80 \pm 0.06$ \\
Transition ecoregion & $14.7 \pm 0.80$ & $2.8 \pm 0.57$ & $0.78 \pm 0.06$ \\
Guineo-Congolian ecoregion & $12.9 \pm 0.98$ & $2.5 \pm 0.63$ & $0.78 \pm 0.05$ \\
\hline
\end{tabular}

ecoregions showed differences in native ant species composition but not for introduced and potentially invasive ant species, which implies that these ants might be common in urban areas (BOLGER et al. 2000). Another reason for the minor difference could be that the introduced and potentially invasive ant species identified here may behave as tramp species and are adapted to urban areas.

In the present study, Paratrechina longicornis was the most common introduced and potentially invasive ant species most frequently encountered and it occurred in all cities sampled. The high prevalence of Paratrechina longicornis might be explained by its opportunistic behaviour that facilitates its adaptation to various environmental conditions and its ability to nest indoors as well as outdoors (WETTERER 2008; AB MAJID et al. 2016). Another potentially invasive ant species, Solenopsis geminata, was collected only from the Industrial zone of Yopougon in Abidjan. The introduction of this species is recent in Côte d'Ivoire as indicated by KOUAKOU et al. (2017). This species has been reported as being highly invasive

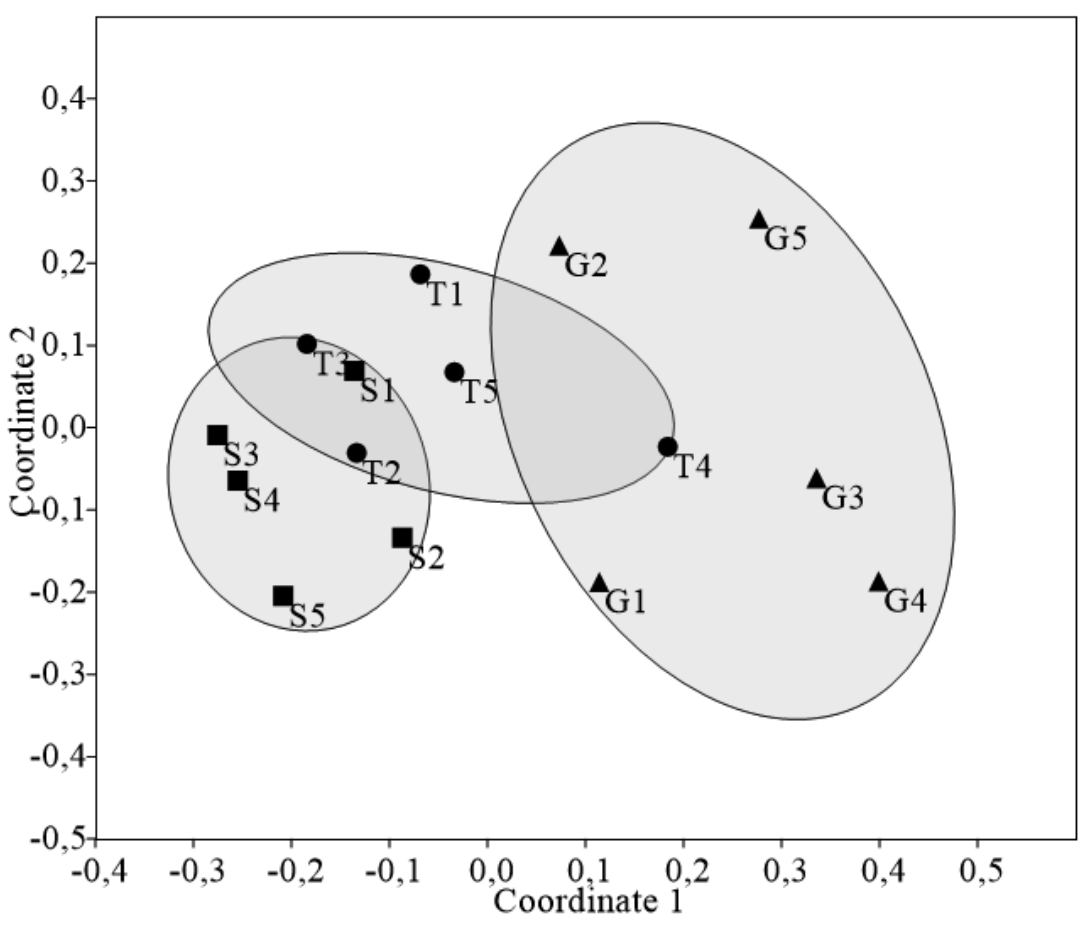

Fig. 5 - Non-metric multidimensional scaling (NMDS) based on the Bray-Curtis similarity index between the sites in ecoregions ( $\mathrm{T}=$ Transition ecoregion; $\mathrm{G}=$ Guineo-Congolian ecoregion; $\mathrm{S}=$ Sudanian ecoregion). City names corresponding to the city codes are given in Material $\&$ methods (see also Fig. 1), Stress value $=0.19$ (NMDS was performed with PAST Software). 
in other regions of the world and is able to monopolize resources in both disturbed and natural areas with respect to other ant species (HERRERA \& CAUSTON 2008; WETTERER 2011; WAUTERS et al. 2014). Also among the introduced and potentially invasive ant species most frequently encountered there were Trichomyrmex destructor, Pheidole megacephala and Tetramorium simillimum, which are abundant and widely distributed in all ecoregion. Pheidole megacephala, a widespread invasive tramp ant species throughout the world and probably native to the Afrotropics (WETTERER 2012), seems commonly distributed in all ecoregions.

Considering the whole ant community of urban areas in the three ecoregions, the rarefaction curve of our study had not plateaued, although our sample coverage showed that we sampled $75 \%$ of the species that would be captured with tuna baits. These results imply that despites the high sampling effort, it may be necessary to conduct further surveys to gain information on complete species richness. This agrees with GoTELLI et al. (2011) who suggested that it is rare to achieve a complete sampling of ants because undetected species can sometimes only be found after (a) decade(s) of continuous sampling. Furthermore, the 103 ant species collected belong to 22 genera and 5 subfamilies for all ecoregions with a predominance of ant species belonging to the subfamily Myrmicinae. This finding is consistent with the previous studies of YEO et al. (2016) on the urban ant fauna in Abidjan municipalities and NARENDRA et al. (2011) who reported that Generalized Myrmicinae co-occurred in disturbed habitats. The partitioning of $\alpha$-diversity into additive component did not show significant variation in the species number at transects and cities level when comparing ecoregions between them. Similarly, spatial scale did not affect the number of introduced and potentially invasive ant species. However, it is important to report that diversity between and within-transect and diversity between-city decreased from the Sudanian ecoregion toward Transition and Guineo-Congolian ecoregions. This variation suggests that the variation in urban ant species diversity is due to the differences of urban area at larger scale, specifically the difference between cities and between ecoregions. This pattern was consistent with dissimilarity observed in the whole ant community composition from cities in the Sudanian ecoregion toward Guineo-Congolian ecoregion. A potential explanation of this difference in ant fauna could be the difference in level of urban land development between cities of the three different ecoregions. Many authors also showed that composition of ant assemblage is strongly linked to habitat and disturbance (NARENDRA et al. 2011; PhiLPOTT et al. 2014; OsSAlA et al. 2015). Here the study areas in the Transition and Guineo-Congolian ecoregions showed a higher frequency of open areas, indicative of apparent level of urban land development, than in the Sudanian ecoregion (Table S1). For example, the cities within the Guineo-Congolian ecoregion have undergone recent rapid urbanization (BAUCHEMIN 2002; RGPH 2014) and are characterized by pavement and open areas with sparse vegetation cover. By contrast, cities in the Sudanian and Transition ecoregion are less homogenous habitats and show a more restricted urban land development and green patches of original vegetation. This result suggests that local factors, such as habitat complexity might explain an important part of the variation of arthropod assemblages, specifically urban ant assemblage (РHILPOTT et al. 2014; OsSALA et al. 2015).

\section{Conclusion}

This study is one of the first to document locally the distribution and diversity of the introduced and potentially invasive ants in urban landscapes in Côte d'Ivoire. We showed that ant communities of urban areas in Côte d'Ivoire seem to host a diverse and often very abundant community of introduced and invasive species. These species may cause problems for the local biodiversity and also economic problems and dangers for human health. This is in particular the case where urban areas border nature reserves and urban parks such as Banco National Park in Abidjan (YEO et al. 2016). We therefore suggest a follow-up and monitoring of potential new introduction pathways for invasive ant species in cities and harbours in Western Africa. 


\section{Acknowledgements}

This research was supported by the Belgian Focal Point for Global Taxonomy Initiative (GTI) under the reference CBD/GTI-02/MLS/2015.53. We are grateful to Frederik Hendrickx and a second reviewer whose suggestions greatly improved the quality of this paper. We are also grateful to Konan Yao Marius, Yodé Dakélé Christine and Kouakou Akissi Evelyne for their helpful technical support during the field activities and identification process.

\section{References}

AB Majid A.H., Ellias S.S., Ahmad H., Hassan A. \& Ahmad H.D. (2016). Tropical household ants species composition and distribution in rapid urbanization area in Penang, Malaysia. Journal of Entomology and Zoology Studies 4: 496-500.

Agosti D. \& Alonso L.E. (2000). The ALL protocol: a standard protocol for the collection of grounddwelling ants. In: Agosti D., MAJer J.D., Alonso L.E. \& Schultz T.R. (eds) Ants: Standard Methods for Measuring and Monitoring Biodiversity: 204-206. Smithsonian Institution Press, Washington DC.

ANDERSEN A.N. (1991). Sampling communities of ground foraging ants: pitfall catches compared with quadrat counts in an Australian tropical savannah. Australian Journal of Ecology 16: 273-279.

Angilletta J.R., Wilson M.J., Niehaus A.C., Sears M.W., Navas C.A. \& Ribeiro P.L. (2007). Urban physiology: city ants possess high heat tolerance. PloS ONE 2: e258.

https://doi.org/10.1371/journal.pone.0000258

ANTWeB. Available from https://www.antweb.org [accessed 15 September 2015].

Avenard J.M., Eldin M., Girard G., Sircoulon J., Touchebeuf P., Guillaumet J.L. \& Adjanohoun E. (1971). Le milieu naturel de la Côte d'Ivoire. Mémoires ORSTOM 50, Muséum national d'Histoire naturelle, Paris.

BEAUCHEMIN C. (2002). Surmonter le doute statistique: le cas de l'émigration urbaine en Côte d'Ivoire. Espace Populations Sociétés 20: 165-177.

Berman M., ANDERSEn A.N., Hély C. \& GAUChERel C. (2013). Overview of the distribution, habitat association and impact of exotic ants on native ant communities in New Caledonia. PloS ONE 8(6): e67245. https://doi.org/10.1371/journal.pone.0067245

Bolger D.T., Suarez A.V., Crooks K.R., Morrison S.A. \& CASe T.J. (2000). Arthropods in urban habitat fragments in southern California: area, age, and edge effects. Ecological Applications 10 (4): 1230-1248. https://doi.org/10.1890/1051-0761(2000)010[1230:AIUHFI]2.0.CO;2

Bolton B. (1976). The ant tribe Tetramoriini (Hymenoptera: Formicidae). Constituent genera, review of smaller genera and review of Triglyphothrix Forel. Bulletin of the British Museum (Natural History), Entomology series 34: 283-379.

Bolton B. (1980). The ant tribe Tetramoriini (Hymenoptera: Formicidae). The genus Tetramorium Mayr, in the Ethiopian Zoogeographical Region. Bulletin of the British Museum (Natural History), Entomology series 40 (3): 193-384.

Bolton B. (1982). Afrotopical species of the myrmicine Cardiocondyla, Leptothorax, Melissotarsus, Messor and Cataulacus (Formicidae) in the Ethiopian. region. Bulletin of the British Museum (Natural History), Entomology series 45 (4): 307-370.

Bolton B. (1987). A review of the Solenopsis genus-group and revision of Afrotropical Monomorium Mayr (Hymenoptera: Formicidae). Bulletin of the British Museum (Natural History), Entomology series 54 (3): $263-452$.

Bolton B. (1994). Identification Guide to the Ant Genera of the World. Harvard University Press. Cambridge, Massachusetts. 
Brecko J., Mathys A., Dekoninck W., Leponce M., Vandenspiegel D. \& Semal P. (2014). Focus stacking: Comparing commercial top-end set-ups with a semi-automatic low budget approach. A possible solution for mass digitization of type specimens. ZooKeys 464: 1-23.

https://doi.org/10.3897/zookeys.464.8615

Chatelain C., Dao H., Gautier L. \& Spichiger R. (2003). Forest cover changes in Côte d'Ivoire and Upper Guinea. In: PoOrTer L., Bongers F., Kouamé F.N'., HaWthorne W.D. (eds) Biodiversity of West African Forests: an Ecological Atlas of Woody Plant Species: 15-32.

Clarke K.R. (1993). Non-parametric multivariate analyses of changes in community structure. Australian Journal of Ecology 18: 117-143.

Clarke K.R. \& Green R.H. (1988). Statistical design and analysis for a "biological effects" study. Marine Ecology Progress Series 46: 213-226.

COLWELl R.K. (2005). EstimateS: Statistical estimation of species richness and shared species from samples. Version 9. Available from purl.oclc.org/estimates [accessed 21 March 2018].

CotTEn A.M. (1974). Un aspect de l'urbanisation en Côte d'Ivoire. Les cahiers d'outre-mer 27: 183193.

Deyrup M., Davis L. \& Cover S. (2000). Exotic ants in Florida. Transactions of the American Entomological Society 126: 293-326.

DiOMANDE T. (1981). Étude du peuplement en fourmis terricoles des forêts ombrophiles climaciques et des zones anthropisées de la Côte d'Ivoire méridionale. PhD Thesis, University of Abidjan, Côted'Ivoire.

EHRENFELD J.G. (2010). Ecosystem consequences of biological invasions. Annual Review of Ecology, Evolution and Systematics 41: 59-80. https://doi.org/10.1146/annurev-ecolsys-102209-144650

FERLAND A. (2015). La conservation de la biodiversité en milieu urbain: comment aménager les villes du monde? Rapport de Maitrise de l'Université de Sherbrooke, Québec, Canada.

GAutier L. \& SPICHIGer R. (2003). The forest-savannah transition in West Africa. In: PoORTer L., BOngers F., KouAmÉ F.N. \& HAWTHORNE W.D. (eds) Biodiversity of West African Forests: an Ecological Atlas of Woody Plant Species: 33-40.

Gotelli N.J., Ellison A.M., DunN R.R. \& SANDERs N.J. (2011). Counting ants (Hymenoptera: Formicidae): Biodiversity sampling and statistical analysis for myrmecologists. Myrmecological News 15: 13-19.

GuÉnARD B., CARdinAl-De CASAS A. \& DunN R.R. (2014). High diversity in an urban habitat: are some animal assemblages resilient to long-term anthropogenic change? Urban Ecosystems 18 (2): 449463. https://doi.org/10.1007/s11252-014-0406-8

Halle B. \& Bruzon V. (2006). Profil environnemental de la Côte d'Ivoire.. Rapport d'Etude pour la Commission Européenne. Rapport final, Consortium AGRIFOR Consult.

HAMMER Ø., HARPER D.A.T. \& RIAN P.D. (2001). PAST: paleontological statistic software package for education and data analysis. Palaeontologia Electronica 4: 1-9.

HerRera H.W. \& CAUSTON C.E. (2008). Distribution of fire ants Solenopsis geminata and Wasmannia auropunctata (Hymenoptera: Formicidae) in the Galapagos Islands. Galapagos Research 65: 11-14.

HöLldobler B. \& Wilson E.O. (1990). The Ants. Harvard University Press, Cambridge MA.

Holway D.A., LACH L., SuArez A.V., Tsutsui N.D. \& CASE T.J. (2002). The causes and consequences of ant invasions. Annual review of Ecology and Systematics 33: 181-233.

https://doi.org/10.1146/annurev.ecolsys.33.010802.150444

HuLME P.E. (2009). Trade, transport and trouble: managing invasive species pathways in an era of globalization. Journal of Applied Ecology 46: 10-18. https://doi.org/10.1111/j.1365-2664.2008.01600.x 
Kark S., IWANiUK A., SchalimtzeK A. \& BAnKer E. (2007). Living in the city: can anyone become an 'urban exploiter'? Journal of Biogeography 34 (4): 638-651.

https://doi.org/10.1111/j.1365-2699.2006.01638.x

KeAY R.W.J. (1959). An Outline of Nigerian Vegetation: 31-48. Government printer, Lagos.

KONÉ M. (2013). Effets de l'intensification des modes d'utilisation des terres et du gradient d'age de la cacaoculture sur la diversité biologique des fourmis en zones préforestière (lamto) et forestière semidécidue (Oumé) de Côte d'Ivoire. PhD Thesis, University Felix Houphouet, Boigny.

Kouakou L.M.M., Yeo K., Vanderheyden A., Kone M., Delsinne T., Ouattara K., Herrera H.W. \& DEKONINCK W. (2017). First morphological and molecular confirmed report of the invasive tropical fire ant, Solenopsis geminata (Fabricius, 1804) (Hymenoptera: Formicidae) from Côte d'Ivoire (West Africa). BioInvasions Records 6 (2): 173-179.

KowArIK I. \& VON Der LiPPE M. (2007). Pathways in plant invasions. Ecological Studies 193: 29-47. https://doi.org/10.1007/978-3-540-36920-2_3

LEVIEUX J. (1971). Données écologiques et biologiques sur le peuplement en fourmis terricoles d'une savane préforestière de Côte d'Ivoire. PhD Thesis, Faculty of Sciences, Paris.

Longino J.T. (2000). What to do with data. In: Agosti D., MAJer J.D., Alonso L.E., Schultz T.R. (eds) Ants: Sandard Methods for Measuring and Monitoring Biodiversity: 186-203. Smithsonian Institution Press, Washington.

MACK R.N. \& LONSDALE W.M. (2001). Humans as global plant dispersers: getting more than we bargained for: current introductions of species for aesthetic purposes present the largest single challenge for predicting which plant immigrants will become future pests. BioScience 51 (2): 95-102. https://doi.org/10.1641/0006-3568(2001)051[0095:HAGPDG]2.0.CO;2

McDonald R.I., Marcotullio P.J. \& GÜNERAlP B. (2013). Urbanization and Global Trends in Biodiversity and Ecosystem Services. In: ElmQvist T., Fragkias M., GoOdness J., GÜNERALP B., Marcotullio P.J., McDonald R.I., Parnell S., Schewenius M., Sendstad M., Seto K.C. \& WILKINSON C. (eds) Urbanization, Biodiversity and Ecosystem Services: Challenges and Opportunities: 31-52. Springer, Netherlands.

MCGLYNN T.P. (1999). The worldwide transfer of ants: geographical distribution and ecological invasions. Journal of Biogeography 26: 535-48. https://doi.org/10.1046/j.1365-2699.1999.00310.x

MCKinNEY M.L. (2006). Urbanization as a major cause of biotic homogenization. Biological Conservation 127: 247-260. https://doi.org/10.1016/j.biocon.2005.09.005

Molina-Montenegro M.A., Carrasco-Urra F., Acuña-Rodriguez I., Oses R, Torres-Diaz C. \& CHWEDORZEWSKA K.J. (2014). Assessing the importance of human activities for the establishment of the invasive Poa annua in Antarctica. Polar Research 33 (1): 21425.

https://doi.org/10.3402/polar.v33.21425

NARENDRA A., GiBB H. \& Ali T.M. (2011). Structure of ant assemblages in Western Ghats, India: role of habitat, disturbance and introduced species. Insect Conservation and diversity 4 (2): 132-141. https://doi.org/10.1111/j.1752-4598.2010.00113.x

Ossala A., Nash M.A., Christie F.J., Hahs A.K. \& LiVeSLEy S.J. (2015). Urban habitat complexity affects species richness but not environmental filtering of morphologically-diverse ants. PeerJ 3: e1356. https://doi.org/10.7717/peerj.1356

Philpott S.M., Cotton J., Bichier P., Friedrich R.L., Moorhead L.C., Uno S. \& Valdez M. (2014). Local and landscape drivers of arthropod abundance, richness, and trophic composition in urban habitats. Urban Ecosystems 17: 513-532. https://doi.org/10.1007/s11252-013-0333-0

Pimentel D. (2011). Biological Invasions: Economic and Environmental Costs of Alien Plant, Animal, and Microbe Species. CRC Press. 
KOUAKOU L.M.M. et al., Introduced and invasive ant communities in Côte d'Ivoire

RGPH. (2014). Recensement général de la population et de l'habitation en Côte d'Ivoire. Available from http://www.ins.ci/n/RESULTATS\%20GLOBAUX.pdf [accessed 6 June 2016].

SARNAT E.M. (2008). PIAkey: Identification Guide to Invasive Ants of the Pacific Islands, Edition 2.0, Lucid v.3.4. USDA/APHIS/PPQ Center for Plant Health Science and Technology and University of California-Davis.

SAVANE I. \& KONARE A. (2010). Le climat. Atlas de la Biodiversité de l'Afrique de l'Ouest 3: 124-125.

SCDB. (2014). Secrétariat de la Convention sur la diversité biologique. 4e édition des perspectives mondiales de la diversité biologique. Montréal, 155 pages. Available from https://www.cbd.int/gbo/ gbo4/publication/gbo4-fr-hr.pdf [accessed 6 June 2016].

Seto K.C., Fragkias M., GÜNeralp B., Reilly M.K. (2011). A meta-analysis of global urban land expansion. PloS ONE 6 (8): e23777. https://doi.org/10.1371/journal.pone.0023777

Seto K.C., PARnell S. \& ElmQvist T. (2013). A global outlook on urbanization. In: ElmQvist T.A., Fragkias M., Goodness J., GÜneralp B., Marcotullio P.J., McDonald R.I., Parnell S., Schewenius M., Sendstad M., Seto K.C. \& Wilkinson C. (eds) Urbanization, Biodiversity and Ecosystem Services: Challenges and Opportunities: 1-12. Springer, Netherlands.

SimBerloff D. \& REJMÁNeK M. (2011). Encyclopedia of Biological Invasions. Volume 3. University of California Press, Oakland.

Simberloff D., Martin J.L., Genovesi P., Maris V., Wardle D.A., Aronson J., Courchamp F., Galil B., García-Berthou E., Pascal M., Pysek P., Sousa R., Tabacchi E. \& Vilá M. (2013). Impacts of biological invasions: what's what and the way forward. Trends in Ecology \& Evolution 28: 58-66. https://doi.org/10.1016/j.tree.2012.07.013

SuAREZ A.V., MCGLYNN T. \& TSUTSUI N.D. (2010). Biogeographic patterns of the origins and spread of introduced ants. In: LACH L., PARR K. \& ABBOT K. (eds) Ant Ecology: 233-244. Oxford University Press, Oxford.

UNITED NATIONS. (2010). World Urbanization Prospects: The 2009 Revision Highlights. United Nations, New York.

Van Ham C., Genovesi P. \& Scalera R. (2013). Invasive Alien Species: the Urban Dimension, Case Studies on Strengthening Local Action in Europe. IUCN European Union Representative Office, Brussels, Belgium.

VON DER LIPPE M. \& KowARIK I. (2008). Do cities export biodiversity? Traffic as dispersal vector across urban-rural gradients. Diversity and Distributions 14 (1): 18-25.

https://doi.org/10.1111/j.1472-4642.2007.00401.x

VONSHAK M. \& GORDON D.M. (2015). Intermediate disturbance promotes invasive ant abundance. Biological Conservation 186: 359-367. https://doi.org/10.1016/j.biocon.2015.03.024

WAGNER H., WiLdi H.O. \& EWALD C.W. (2000). Additive partitioning of plant species diversity in an agricultural mosaic landscape. Landscape Ecology 15 (3): 219-227. https://doi.org/10.1023/A:1008114117913

Wauters N., DeKoninck W., Herrera H.W. \& Fournier D. (2014). Distribution, behavioral dominance and potential impacts on endemic fauna of tropical fire ant Solenopsis geminata (Fabricius, 1804) (Hymenoptera: Formicidae: Myrmicinae) in the Galápagos archipelago. Pan-Pacific Entomologist 90 (4): 205-220. https://doi.org/10.3956/2014-90.4.205

Wetterer J.K. (2008). Worldwide spread of the longhorn crazy ant, Paratrechina longicornis (Hymenoptera: Formicidae). Myrmecological News 11: 137-149.

WetTERER J.K. (2010a). Worldwide spread of the pharaoh ant, Monomorium pharaonis (Hymenoptera: Formicidae). Myrmecological News 13: 115-129. 
WetTERER J.K. (2010b). Worldwide spread of the flower ant, Monomorium floricola (Hymenoptera: Formicidae). Myrmecological News 13: 19-27.

WetTERER J.K. (2011). Worldwide spread of the tropical fire ant, Solenopsis geminata (Hymenoptera: Formicidae). Myrmecological News 14 (1): 21-35.

WetTerer J.K. (2012). Worldwide spread of the African big-headed ant, Pheidole megacephala (Hymenoptera: Formicidae). Myrmecological News 17: 51-62.

WETTERER J.K. (2015). Geographic origin and spread of cosmopolitan ants (Hymenoptera: Formicidae). Halteres 6: 66-78.

WeTterer J.K. \& GARCIA F.H. (2015). Worldwide spread of Tetramorium caldarium (Hymenoptera: Formicidae). Myrmecological News 21: 93-99.

WHITE F (1983). The Vegetation of Africa, a Descriptive Memoir to Accompany the UNESCO/AETFAT/ UNSO Vegetation Map of Africa. UNESCO, Paris.

YEO K. (2006). Dynamique spatiale et diversité des fourmis de la litière et du sol dans une mosaïque foret-savane en Côte d'Ivoire. PhD Thesis, University Pierre Marie Curie and University of Abobo Adjamé.

Yeo K., KonAtE S., TiHo S. \& CAMARA S.K. (2011). Impacts of land use types on ant communities in a tropical forest margin (Oumé-Côte d'Ivoire). African Journal of Agricultural Research 6 (1): 260-274.

Yeo K., Kouakou L.M., Dekoninck W., Ouattara K. \& Konate S. (2016). Detecting intruders: assessment of the anthropophilic ant fauna (Hymenoptera: Formicidae) in the city of Abidjan and along access roads in Banco National Park (Côte d'Ivoire). Journal of Entomology and Zoology Studies 4 (4): 351-359.

Manuscript received: 31 January 2017

Manuscript accepted: 5 March 2018

Published on: 4 May 2018

Branch editor: Frederik Hendrickx 


\section{Appendix}

\section{TABLE S1}

Location coordinates and brief description of transects for surveyed cities. Street of household: road, street and spaces between buildings; Market: sites near traditional daily markets; Residential: houses where people of middle-class live; Asphalted street: road dominated by asphalt; Transport station: sites of transport of people and goods; Industrial zone: zone dominated by industrial activities such as production, transformation, exportation and importation of goods; Port zone: Port area of Abidjan and San-Pedro. The latter two types of habitat are linked to ports.

\begin{tabular}{|c|c|c|c|c|}
\hline Cities & Sites & Coordinates & $\begin{array}{c}\text { Specific habi- } \\
\text { tats }\end{array}$ & Description \\
\hline \multirow{3}{*}{$\overline{\text { Odienné (S1) }}$} & Residentiel Sud & $09^{\circ} 30^{\prime} 15.2^{\prime \prime} \mathrm{N}, 007^{\circ} 33^{\prime} 09.4^{\prime \prime} \mathrm{W}$ & Residential & bush, trees \\
\hline & Libreville & $09^{\circ} 30^{\prime} 41.4^{\prime \prime} \mathrm{N}, 007^{\circ} 33^{\prime} 55.3^{\prime \prime} \mathrm{W}$ & $\begin{array}{l}\text { Street of house- } \\
\text { hold }\end{array}$ & Open area \\
\hline & Marché & $09^{\circ} 30^{\prime} 07.3^{\prime \prime} \mathrm{N}, 007^{\circ} 33^{\prime} 48.9^{\prime \prime} \mathrm{W}$ & Market & Open area with lawn \\
\hline \multirow[t]{3}{*}{ Korhogo (S2) } & Gendarmerie & $09^{\circ} 28^{\prime} 06.6^{\prime \prime} \mathrm{N}, 005^{\circ} 36^{\prime} 59.4^{\prime \prime} \mathrm{W}$ & $\begin{array}{l}\text { Street of house- } \\
\text { hold }\end{array}$ & Open area \\
\hline & Marché & $09^{\circ} 27^{\prime} 25.9^{\prime \prime} \mathrm{N}, 005^{\circ} 37^{\prime} 59.0^{\prime \prime} \mathrm{W}$ & Market & Open area with lawn \\
\hline & Air-France & $09^{\circ} 26^{\prime} 59.0^{\prime \prime} \mathrm{N}, 005^{\circ} 37^{\prime} 29.8^{\prime \prime} \mathrm{W}$ & $\begin{array}{l}\text { Street of house- } \\
\text { hold }\end{array}$ & $\begin{array}{c}\text { Grass, trees and } \\
\text { lawn }\end{array}$ \\
\hline \multirow[t]{3}{*}{ Bouna (S3) } & Stade & $09^{\circ} 16^{\prime} 19.7^{\prime \prime} \mathrm{N}, 002^{\circ} 59^{\prime} 33.3^{\prime \prime} \mathrm{W}$ & $\begin{array}{l}\text { Street of house- } \\
\text { hold }\end{array}$ & Open area with law \\
\hline & Résidentiel & $09^{\circ} 15^{\prime} 39.4^{\prime \prime} \mathrm{N}, 003^{\circ} 00^{\prime} 07.2^{\prime \prime} \mathrm{W}$ & Residential & bush, lawn \\
\hline & Gare routière & $09^{\circ} 16^{\prime} 16.9^{\prime \prime} \mathrm{N}, 003^{\circ} 00^{\prime} 037.8^{\prime \prime} \mathrm{W}$ & Transport station & Open area with lawn \\
\hline \multirow{3}{*}{$\begin{array}{l}\text { Ferkéssedougou } \\
\text { (S4) }\end{array}$} & Marché & $09^{\circ} 35^{\prime} 27.1^{\prime \prime} \mathrm{N}, 005^{\circ} 11^{\prime} 38.8^{\prime \prime} \mathrm{W}$ & Market & Open area \\
\hline & Prefecture & $09^{\circ} 36^{\prime} 32.4^{\prime \prime} \mathrm{N}, 005^{\circ} 11^{\prime} 23.7^{\prime \prime} \mathrm{W}$ & $\begin{array}{l}\text { Street of house- } \\
\text { hold }\end{array}$ & Open area with lawn \\
\hline & Dioulabougou & $09^{\circ} 35^{\prime} 21.4^{\prime \prime} \mathrm{N}, 005^{\circ} 12^{\prime} 16.0^{\prime \prime} \mathrm{W}$ & $\begin{array}{l}\text { Street of house- } \\
\text { hold }\end{array}$ & High grass and lawn \\
\hline \multirow[t]{3}{*}{ Ouangolo (S5) } & Gare de train & $09^{\circ} 57^{\prime} 53.9^{\prime \prime} \mathrm{N}, 005^{\circ} 08^{\prime} 37.9^{\prime \prime} \mathrm{W}$ & $\begin{array}{l}\text { Street of house- } \\
\text { hold }\end{array}$ & $\begin{array}{l}\text { Open area, grass, } \\
\text { trees }\end{array}$ \\
\hline & Marché & $09^{\circ} 58^{\prime} 01.3^{\prime \prime} \mathrm{N}, 005^{\circ} 09^{\prime} 09.3^{\prime \prime} \mathrm{W}$ & Market & Open area \\
\hline & Residentiel & $09^{\circ} 58^{\prime} 19.4^{\prime \prime} \mathrm{N}, 005^{\circ} 09^{\prime} 18.0^{\prime \prime} \mathrm{W}$ & Residential & High grass and lawn \\
\hline \multirow[t]{4}{*}{ Bouaké (T1) } & Air-France 2 & $07^{\circ} 40^{\prime} 06.0^{\prime \prime} \mathrm{N}, 005^{\circ} 00^{\prime} 57^{\prime \prime} \mathrm{W}$ & $\begin{array}{l}\text { Street of house- } \\
\text { hold }\end{array}$ & Open area \\
\hline & Koko & $07^{\circ} 41^{\prime} 24.3^{\prime \prime} \mathrm{N}, 005^{\circ} 02^{\prime} 42.3^{\prime \prime} \mathrm{W}$ & Industrial zone & Open area with lawn \\
\hline & Kennedy & $07^{\circ} 41^{\prime} 12.5^{\prime \prime} \mathrm{N}, 005^{\circ} 00^{\prime} 22.8^{\prime \prime} \mathrm{W}$ & Asphalted street & Trees, shade \\
\hline & Dioulabougou & $06^{\circ} 48^{\prime} 14.9^{\prime \prime} \mathrm{N}, 005^{\circ} 15^{\prime} 57.4^{\prime \prime} \mathrm{W}$ & $\begin{array}{l}\text { Street of house- } \\
\text { hold }\end{array}$ & Open area with lawn \\
\hline \multirow{2}{*}{$\begin{array}{l}\text { Yamoussoukro } \\
\text { (T2) }\end{array}$} & Lycée Mixte & $06^{\circ} 49^{\prime} 15.5^{\prime \prime} \mathrm{N}, 005^{\circ} 15^{\prime} 03.9^{\prime \prime} \mathrm{W}$ & Asphalted street & Open area with lawn \\
\hline & Habitat & $06^{\circ} 49^{\prime} 33.44^{\prime \prime} \mathrm{N}, 005^{\circ} 16^{\prime} 32.2^{\prime \prime} \mathrm{W}$ & $\begin{array}{l}\text { Street of house- } \\
\text { hold }\end{array}$ & Open area with lawn \\
\hline
\end{tabular}




\begin{tabular}{|c|c|c|c|c|}
\hline Cities & Sites & Coordinates & $\begin{array}{c}\text { Specific habi- } \\
\text { tats }\end{array}$ & Description \\
\hline \multirow[t]{3}{*}{ Touba (T3) } & Marché & $08^{\circ} 17^{\prime} 14.8^{\prime \prime} \mathrm{N}, 007^{\circ} 40^{\prime} 53.7^{\prime \prime} \mathrm{W}$ & Market & Open area \\
\hline & Sokoura 2 & $08^{\circ} 17^{\prime} 48.7^{\prime \prime} \mathrm{N}, 007^{\circ} 40^{\prime} 47.6^{\prime \prime} \mathrm{W}$ & $\begin{array}{l}\text { Street of house- } \\
\text { hold }\end{array}$ & High grass \\
\hline & Residentiel & $08^{\circ} 17^{\prime} 08.7^{\prime \prime} \mathrm{N}, 007^{\circ} 41^{\prime} 26.3^{\prime \prime} \mathrm{W}$ & Residential & $\begin{array}{c}\text { Open area short } \\
\text { grass }\end{array}$ \\
\hline \multirow[t]{3}{*}{ Bondoukou (T4) } & Impôt & $08^{\circ} 02^{\prime} 16.4^{\prime \prime} \mathrm{N}, 002^{\circ} 48^{\prime} 06.7^{\prime \prime} \mathrm{W}$ & $\begin{array}{l}\text { Street of house- } \\
\text { hold }\end{array}$ & Open area \\
\hline & Justice & $08^{\circ} 02^{\prime} 34.0^{\prime \prime} \mathrm{N}, 002^{\circ} 47^{\prime} 40.9^{\prime \prime} \mathrm{W}$ & $\begin{array}{c}\text { Street of house- } \\
\text { hold }\end{array}$ & Open area with lawn \\
\hline & Hotel la paix & $08^{\circ} 02^{\prime} 52.3^{\prime \prime} \mathrm{N}, 002^{\circ} 48^{\prime} 11.4^{\prime \prime} \mathrm{W}$ & $\begin{array}{l}\text { Street of house- } \\
\text { hold }\end{array}$ & $\begin{array}{l}\text { Hollow, grass and } \\
\text { trees }\end{array}$ \\
\hline \multirow[t]{3}{*}{$\begin{array}{l}\text { Abengourou } \\
\text { (T5) }\end{array}$} & Mosquée & $06^{\circ} 43^{\prime} 47.6^{\prime \prime} \mathrm{N}, 003^{\circ} 29^{\prime} 42.1^{\prime \prime} \mathrm{W}$ & $\begin{array}{l}\text { Street of house- } \\
\text { hold }\end{array}$ & $\begin{array}{l}\text { Open area, short } \\
\text { grass }\end{array}$ \\
\hline & Affetou & $06^{\circ} 43^{\prime} 16.2^{\prime \prime} \mathrm{N}, 003^{\circ} 29^{\prime} 46.8^{\prime \prime} \mathrm{W}$ & $\begin{array}{c}\text { Street of house- } \\
\text { hold }\end{array}$ & Open area \\
\hline & Cathédrale & $06^{\circ} 43^{\prime} 43.8^{\prime \prime} \mathrm{N}, 003^{\circ} 29^{\prime} 03.1^{\prime \prime} \mathrm{W}$ & Asphalted street & $\begin{array}{l}\text { Grass with trees, } \\
\text { shade }\end{array}$ \\
\hline \multirow[t]{3}{*}{ Daloa (G1) } & Marais & $06^{\circ} 52^{\prime} 10.5^{\prime \prime} \mathrm{N}, 006^{\circ} 26^{\prime} 58.4^{\prime \prime} \mathrm{W}$ & $\begin{array}{l}\text { Street of house- } \\
\text { hold }\end{array}$ & Open area \\
\hline & Commerce & $06^{\circ} 53^{\prime} 19.0^{\prime \prime} \mathrm{N}, 006^{\circ} 27^{\prime} 08.1^{\prime \prime} \mathrm{W}$ & Asphalted street & Open area \\
\hline & Tazibouo 1 & $06^{\circ} 53^{\prime} 41.1^{\prime \prime} \mathrm{N}, 006^{\circ} 26^{\prime} 23.0^{\prime \prime} \mathrm{W}$ & $\begin{array}{l}\text { Street of house- } \\
\text { hold }\end{array}$ & $\begin{array}{c}\text { Open area with } \\
\text { lown }\end{array}$ \\
\hline \multirow[t]{3}{*}{ Man (G2) } & Gare & $07^{\circ} 24^{\prime} 48.0^{\prime \prime} \mathrm{N}, 007^{\circ} 32^{\prime} 51.9^{\prime \prime} \mathrm{W}$ & Transport station & Open area \\
\hline & Justice & $07^{\circ} 24^{\prime} 23.4^{\prime \prime} \mathrm{N}, 007^{\circ} 33^{\prime} 15.2^{\prime \prime} \mathrm{W}$ & $\begin{array}{l}\text { Street of house- } \\
\text { hold }\end{array}$ & Open area \\
\hline & Cafop & $07^{\circ} 23^{\prime} 43.2^{\prime \prime} \mathrm{N}, 007^{\circ} 33^{\prime} 32.9^{\prime \prime} \mathrm{W}$ & $\begin{array}{l}\text { Street of house- } \\
\text { hold }\end{array}$ & Open area with lawn \\
\hline \multirow[t]{3}{*}{ San-Pedro (G3) } & Lycée Moderne & $04^{\circ} 45^{\prime} 29.2^{\prime \prime} \mathrm{N}, 006^{\circ} 40^{\prime} 50.2^{\prime \prime} \mathrm{W}$ & $\begin{array}{l}\text { Street of house- } \\
\text { hold }\end{array}$ & Open area \\
\hline & CMA & $04^{\circ} 46^{\prime} 26.0^{\prime \prime} \mathrm{N}, 006^{\circ} 40^{\prime} 23.2^{\prime \prime} \mathrm{W}$ & $\begin{array}{l}\text { Street of house- } \\
\text { hold }\end{array}$ & Open area \\
\hline & Millionnaire & $04^{\circ} 44^{\prime} 42.0^{\prime \prime} \mathrm{N}, 006^{\circ} 38^{\prime} 06.6^{\prime \prime} \mathrm{W}$ & Port zone & Open area with lawn \\
\hline \multirow[t]{3}{*}{ Soubre (G4) } & Gbakalepka & $05^{\circ} 48^{\prime} 21.1^{\prime \prime} \mathrm{N}, 006^{\circ} 35^{\prime} 22.1^{\prime \prime} \mathrm{W}$ & $\begin{array}{l}\text { Street of house- } \\
\text { hold }\end{array}$ & Trees and lawn \\
\hline & Château & $05^{\circ} 47^{\prime} 23.0^{\prime \prime} \mathrm{N}, 006^{\circ} 35^{\prime} 35.8^{\prime \prime} \mathrm{W}$ & $\begin{array}{c}\text { Street of house- } \\
\text { hold }\end{array}$ & Open area \\
\hline & Dalas & $05^{\circ} 46^{\prime} 39.5^{\prime \prime} \mathrm{N}, 006^{\circ} 35^{\prime} 43.9^{\prime \prime} \mathrm{W}$ & $\begin{array}{l}\text { Street of house- } \\
\text { hold }\end{array}$ & Open area \\
\hline \multirow[t]{3}{*}{ Abidjan (G5) } & Adjamé Bracodi & $05^{\circ} 21^{\prime} 37.4^{\prime \prime} \mathrm{N}, 004^{\circ} 01^{\prime} 16.5^{\prime \prime} \mathrm{W}$ & $\begin{array}{l}\text { Street of house- } \\
\text { hold }\end{array}$ & Open area \\
\hline & Port commerce & $05^{\circ} 17^{\prime} 32.6^{\prime \prime} \mathrm{N}, 004^{\circ} 00^{\prime} 29.4^{\prime \prime} \mathrm{W}$ & Port zone & Open area \\
\hline & $\begin{array}{l}\text { Zone Indus- } \\
\text { trielle }\end{array}$ & $05^{\circ} 22^{\prime} 12.9^{\prime \prime} \mathrm{N}, 004^{\circ} 05^{\prime} 29.9^{\prime \prime} \mathrm{W}$ & Industrial zone & Open area \\
\hline
\end{tabular}


TABLE S2

List of ants collected and their total occurrences in the urban area. ${ }^{*}=$ introduced and potentially invasive ant species

\begin{tabular}{|c|c|c|c|c|}
\hline & $\begin{array}{l}\text { Sudanian } \\
\text { ecoregion }\end{array}$ & $\begin{array}{l}\text { Transition } \\
\text { ecoregion }\end{array}$ & $\begin{array}{c}\text { Guineo-Congo- } \\
\text { lian ecoregion }\end{array}$ & Total \\
\hline \multicolumn{5}{|c|}{ Dorylinae } \\
\hline Aenictus sp.1 & 1 & 0 & 0 & 1 \\
\hline Parasyscia nitidulus (Brown, 1975) & 0 & 0 & 1 & 1 \\
\hline Parasyscia sp. 1 & 1 & 0 & 0 & 1 \\
\hline \multicolumn{5}{|c|}{ Dolichoderinae } \\
\hline Tapinoma lugubre Santschi, 1917 & 1 & 19 & 33 & 53 \\
\hline Tapinoma luteum Emery, 1895 & 6 & 10 & 136 & 152 \\
\hline Tapinoma melanocephalum Fabricius, $1793 *$ & 0 & 1 & 25 & 26 \\
\hline Tapinoma sp.1 & 0 & 0 & 4 & 4 \\
\hline \multicolumn{5}{|c|}{ Formicinae } \\
\hline Camponotus acvapimensis Mayr, 1862 & 4 & 13 & 5 & 22 \\
\hline Camponotus maculatus Fabricius, 1782 & 3 & 3 & 4 & 10 \\
\hline Camponotus sericeus Fabricus, 1798 & 4 & 9 & 0 & 13 \\
\hline Camponotus sp.1 & 0 & 1 & 0 & 1 \\
\hline Camponotus sp.2 & 0 & 1 & 0 & 1 \\
\hline Camponotus sp.3 & 1 & 0 & 0 & 1 \\
\hline Camponotus sp.4 & 1 & 0 & 0 & 1 \\
\hline Camponotus sp.5 & 1 & 0 & 0 & 1 \\
\hline Camponotus sp.6 & 11 & 17 & 0 & 28 \\
\hline Camponotus vividus Smith, 1858 & 3 & 6 & 0 & 9 \\
\hline Lepisiota capensis Mayr, 1862 & 34 & 10 & 10 & 54 \\
\hline Nylanderia incallida (Santschi, 1915 ) & 0 & 0 & 13 & 13 \\
\hline Nylanderia jaegerskioeldi Santschi, 1911 & 6 & 19 & 38 & 63 \\
\hline Oecophylla longinoda Latreille, 1802 & 0 & 0 & 1 & 1 \\
\hline Paratrechina longicornis Latreille, $1802^{*}$ & 116 & 159 & 198 & 473 \\
\hline \multicolumn{5}{|c|}{ Myrmicinae } \\
\hline Cardiocondyla emeryi Forel, 1881* & 14 & 21 & 29 & 54 \\
\hline Cardiocondyla shuckardi Forel, 1891 & 8 & 9 & 13 & 30 \\
\hline Cardiocondyla sp.1 & 6 & 0 & 3 & 9 \\
\hline Cardiocondyla sp.2 & 0 & 10 & 0 & 10 \\
\hline Cardiocondyla sp.3 & 0 & 1 & 0 & 1 \\
\hline Carebara distincta (Bolton \& Belshaw, 1993) & 0 & 1 & 0 & 1 \\
\hline Crematogaster sp.1 & 1 & 0 & 0 & 1 \\
\hline Crematogaster sp. 2 & 0 & 1 & 0 & 1 \\
\hline
\end{tabular}




\begin{tabular}{|c|c|c|c|c|}
\hline & $\begin{array}{l}\text { Sudanian } \\
\text { ecoregion }\end{array}$ & $\begin{array}{l}\text { Transition } \\
\text { ecoregion }\end{array}$ & $\begin{array}{l}\text { Guineo-Congo- } \\
\text { lian ecoregion }\end{array}$ & Total \\
\hline Crematogaster $\mathrm{sp} .3$ & 0 & 2 & 0 & 2 \\
\hline Messor galla Mayr, 1904 & 12 & 0 & 0 & 12 \\
\hline Monomorium afrum Andre, 1884 & 25 & 0 & 0 & 25 \\
\hline Monomorium bicolor Emery, 1877 & 313 & 361 & 271 & 945 \\
\hline Monomorium dolatu Bolton, 1987 & 1 & 43 & 20 & 64 \\
\hline Monomorium ехіgиит Forel, 1894 & 27 & 15 & 0 & 42 \\
\hline Monomorium floricola Jerdon, $1851^{*}$ & 0 & 2 & 2 & 4 \\
\hline Monomorium invidium Bolton, 1987 & 4 & 2 & 0 & 6 \\
\hline Monomorium occidentale Bernard, 1953 & 4 & 58 & 135 & 197 \\
\hline Monomorium pharaonis ( Linnaeus, 1758)* & 37 & 1 & 29 & 68 \\
\hline Monomorium rosae Santschi, 1920 & 7 & 6 & 4 & 17 \\
\hline Monomorium sp.1 & 59 & 4 & 0 & 63 \\
\hline Monomorium sp.2 & 0 & 2 & 0 & 2 \\
\hline Monomorium sp.3 & 0 & 0 & 1 & 1 \\
\hline Monomorium sp.4 & 0 & 1 & 0 & 1 \\
\hline Monomorium sp.5 & 1 & 0 & 0 & 1 \\
\hline Monomorium sp.6 & 1 & 0 & 0 & 1 \\
\hline Monomorium sp.7 & 1 & 0 & 0 & 1 \\
\hline Monomorium sp. 8 & 0 & 1 & 0 & 1 \\
\hline Monomorium sp.9 & 3 & 0 & 0 & 3 \\
\hline Monomorium sp.10 & 1 & 0 & 0 & 1 \\
\hline Monomorium sp.11 & 1 & 0 & 0 & 1 \\
\hline Monomorium sp.12 & 10 & 0 & 0 & 10 \\
\hline Myrmicaria sp.1 & 4 & 0 & 0 & 4 \\
\hline Pheidole sp.1 & 47 & 2 & 12 & 61 \\
\hline Pheidoles termitophila Forel, 1904 & 139 & 76 & 205 & 420 \\
\hline Pheidole excellens Mayr, 1862 & 4 & 81 & 19 & 104 \\
\hline Pheidole megacephala Fabricius, 1793* & 46 & 75 & 41 & 162 \\
\hline Pheidole sp.1 & 259 & 67 & 0 & 326 \\
\hline Pheidole sp.2 & 69 & 112 & 149 & 330 \\
\hline Pheidole sp.3 & 0 & 0 & 14 & 14 \\
\hline Pheidole sp.4 & 1 & 0 & 4 & 5 \\
\hline Pheidole sp.5 & 2 & 0 & 0 & 2 \\
\hline Pheidole sp.6 & 10 & 0 & 0 & 10 \\
\hline Pheidole sp.7 & 0 & 1 & 0 & 1 \\
\hline Pheidole sp.8 & 0 & 0 & 1 & 1 \\
\hline Pheidole sp.9 & 3 & 0 & 0 & 3 \\
\hline
\end{tabular}


KOUAKOU L.M.M. et al., Introduced and invasive ant communities in Côte d'Ivoire

\begin{tabular}{|c|c|c|c|c|}
\hline & $\begin{array}{l}\text { Sudanian } \\
\text { ecoregion }\end{array}$ & $\begin{array}{l}\text { Transition } \\
\text { ecoregion }\end{array}$ & $\begin{array}{l}\text { Guineo-Congo- } \\
\text { lian ecoregion }\end{array}$ & Total \\
\hline Pheidole sp.18 & 0 & 0 & 46 & 46 \\
\hline Pheidole sp.19 & 10 & 27 & 99 & 136 \\
\hline Pheidole sp.20 & 99 & 49 & 45 & 190 \\
\hline Pheidole sp.21 & 0 & 0 & 32 & 32 \\
\hline Pheidole sp.22 & 2 & 0 & 0 & 2 \\
\hline Pheidole sp.23 & 6 & 0 & 0 & 6 \\
\hline Pyramica sp.1 & 0 & 0 & 1 & 1 \\
\hline Solenopsis geminata Fabricius, 1804* & 0 & 0 & 22 & 22 \\
\hline Solenopsis globularia Smith, 1858 & 0 & 15 & 80 & 95 \\
\hline Tetramorium caldarium (Roger, 1857$)^{*}$ & 20 & 0 & 3 & 23 \\
\hline Tetramorium calinum Bolton, 1980 & 16 & 0 & 0 & 16 \\
\hline Tetramorium eminii, (Forel, 1894) & 4 & 0 & 1 & 5 \\
\hline Tetramorium minusculum Santschi, 1914 & 0 & 0 & 6 & 6 \\
\hline Tetramorium rhetidum Bolton, 1980 & 0 & 8 & 17 & 25 \\
\hline Tetramorium sepositum Santschi,1918 & 0 & 5 & 2 & 7 \\
\hline Tetramorium sericeiventre Emery, 1877 & 32 & 43 & 16 & 91 \\
\hline Tetramorium simillimum Smith, 1851* & 26 & 48 & 118 & 192 \\
\hline Tetramorium sp.1 & 0 & 2 & 0 & 2 \\
\hline Tetramorium sp.2 & 0 & 2 & 0 & 2 \\
\hline Tetramorium sp. 3 & 0 & 0 & 1 & 1 \\
\hline Tetramorium sp. 4 & 0 & 0 & 1 & 1 \\
\hline Tetramorium sp.6 & 0 & 0 & 1 & 1 \\
\hline Tetramorium sp.5 & 0 & 2 & 0 & 2 \\
\hline Tetramorium sp.7 & 0 & 0 & 4 & 4 \\
\hline Tetramorium sp. 8 & 0 & 0 & 3 & 3 \\
\hline Tetramorium sp.9 & 0 & 0 & 4 & 4 \\
\hline Tetramorium sp.11 & 2 & 0 & 0 & 2 \\
\hline Tetramorium sp. 12 & 0 & 0 & 1 & 1 \\
\hline Tetramorium zapyrum Bolton, 1980 & 0 & 1 & 0 & 1 \\
\hline Trichomyrmex abyssinicus (Forel, 1894) & 16 & 0 & 0 & 16 \\
\hline Trichomyrmex destructor Jerdon, $1851^{*}$ & 4 & 72 & 84 & 160 \\
\hline Trichomyrmex oscaris (Forel, 1894) & 17 & 15 & 32 & 64 \\
\hline \multicolumn{5}{|c|}{ Ponerinae } \\
\hline Brachyponera sennaarensis Mayr, 1862 & 130 & 155 & 10 & 295 \\
\hline Mesoponera ambigua Andre, 1890 & 0 & 0 & 1 & 1 \\
\hline Mesoponera caffraria Smith, 1858 & 2 & 0 & 0 & 2 \\
\hline Odontomachus troglodytes Santschi, 1914 & 9 & 8 & 10 & 28 \\
\hline
\end{tabular}

